\title{
ECOFRIENDLY TECHNOLOGY FOR THE MANAGEMENT OF BRINJAL PEST USING REDUVIIDS
}

\author{
Bibin.G.Anand, ${ }^{1}$ Fathima Rizwana A. $^{2}$ Prakash $\mathbf{S}^{3}$ \\ ${ }^{1}$ Udaya School of Engineering, Vellamodi, K.K dist \\ E-mail:bibin_g_anand@yahoo.co.in
}

\begin{abstract}
Eco-friendly technology nowadays is an important event to maintain the pollutant free and safe environment. Such condition to certain extent may be provided by the predatory insects namely the reduviids. They act as bio-control agents on insect pests and play an effective role in eco-friendly technology. To prove reduviids as effective bio control agent on insect pest, the functional response experiment was carried out in the pest of Solanum melongena Linn (brinjal) the Pterophorus lienigianus (Z) in a brinjal agro ecosystem, using the reduviid predators Rhynocoris fuscipes (Fabricius) and Endocus inornatus (Stal).The number of prey was kept constant through out the experimental period."Disc"equation of Holling (1959) $Y=a$ (Tt - by) $x$ was used to describe the functional response of both predators. Study on the functional response in $R$. fuscipes and $E$. inornatus suggested that both were capable of suppressing the pest population by killing more number of pests. Hence they could be mass cultured and effectively employed as bio control agent for suppressing the pest population of brinjal. Managing the pest by using natural predators will minimize the usage of pesticides, and make the environment free from toxic pollutant.
\end{abstract}

Keywords: Pollllution reduviids, Solanum Melongena Linn, Endocus Inornaths

\section{INTRODUCTION}

Biological control by predators such as assassin bugs help in the regulation of insect pest population in Integrated Pest Management (IPM). Biological control refers to the regulatory action of parasites, predators or pathogens to maintain the density of an organism (pest) at a lower level than would occur without these natural enemies. Reduviids are exclusively predatory mostly on insect pests. They have good searching ability, a high degree of host specificity and higher reproductive capacity and are amenable to mass culture. They attack a greater number of prey at higher prey density than at a lower prey density (Mc Mahan, ,1983). Since they are specific, safer to non target species, beneficial insects of higher animals and man and have the least effect on the ecosystem, they have been used as highly successful group of bio control agent in Insect Pest Management to maintain an eco-friendly environment.

\section{R.fuscipes and E. inornatus the} entomosuccivorous, polyphagous, crepuscular, assassin bugs are excellent predators predominantly found in agro ecosystems in India. They are the potent bio control predator of insect pests such as Spodoptera litura Fabricius, Helicoverpa armigera Hubner, Mylabris pustulata Thunberg, Dysdercus cingulatus Fabricius, and Achaea janata Linnaeus (Ambrose, 1996).
However there is no report available on the eco-friendly technology of $R$. fuscipes and $E$. inornatus in the brinjal pest. Hence an attempt was made to asses the eco-friendly technology for the management of brinjal pest by way of studying the prey consumption in relation to prey density (functional response) of $R$. fuscipes and $E$. inornatus on $P$. lienigianus - the pest of $S$ melongena.

\section{MATERIALS AND METHOD}

The laboratory raised adult females of $R$. fuscipes and $E$. inornatus starved for 24 hours were used in this experiment. The functional response experiments were performed in the infested S.melongena agro ecosystem at Vellamodi village, in kanyakumari district of Tamilnadu. In field trials on functional response, one female predator of each species was allowed on the branches of infested brinjal and covered over by synthetic net material. The prey was also within the net cover. The branches were selected in such a way that the particular portion of the branch had $1,2,4,8$ or 16 rolled leaves containing an equivalent number of cater pillars of the P.lienigianus. The rolled leaves were slightly opened exposing the pest partially enabling the predator to track the prey easily.

Thus, five different categories of experimental setup with five different prey levels were maintained 
separately for each set up for 6 days. Six replicates were made for each category. After 24 hours the number of prey consumed or killed was monitored and the prey number was maintained constant by using other infested plants throughout the experimental period. "Disc" equation of Holling (1959) ' $Y$ ' $=\mathrm{a}(\mathrm{Tt}-\mathrm{by}) \mathrm{X}$ was used to describe the functional response of both predators to P.lienigianus

\section{Where}

$$
\begin{aligned}
& \mathrm{X}=\text { Prey density } \\
& \mathrm{Y}=\begin{array}{l}
\text { Total number of prey killed in given } \\
\text { period of time }(\mathrm{Tt})
\end{array} \\
& \mathrm{Tt}=\begin{array}{l}
\text { Total time in days for which prey was } \\
\text { exposed to the predator }
\end{array} \\
& \mathrm{b}=\text { Handing time in days } \\
& \mathrm{a}=\begin{array}{l}
\text { Rate of discovery per unit of searching } \\
\text { time }(\mathrm{y} / \mathrm{x} / \mathrm{Ts})
\end{array} \\
& \mathrm{Y} / \mathrm{X}=\text { Attack ratio } \\
& \mathrm{Ts}=\text { Searching time in days }
\end{aligned}
$$

\begin{tabular}{|c|c|c|c|c|c|c|c|c|c|c|}
\hline & $\begin{array}{l}\text { Prey } \\
\text { density }\end{array}$ & $\begin{array}{c}\text { Prey } \\
\text { attacked y }\end{array}$ & $\operatorname{Max} Y(k)$ & $\begin{array}{c}\text { Days } / \\
Y \\
b=T t / K\end{array}$ & $\begin{array}{l}\text { Days all } \\
\text { y's (by) }\end{array}$ & \begin{tabular}{|c|} 
Days \\
searching \\
Ts $=\mathrm{Tt}-$ by
\end{tabular} & $\begin{array}{l}\text { Attack } \\
\text { ratio } y / x\end{array}$ & $\begin{array}{c}\text { Rate of } \\
\text { Discovery } \\
(\mathrm{y} / \mathbf{x}) / \mathrm{Ts}=\mathrm{a}\end{array}$ & $\begin{array}{c}\text { Disc equation } \\
Y^{\prime}=a(T t-b y) x\end{array}$ & $Y^{\prime}$ \\
\hline \multirow{5}{*}{$\begin{array}{c}R \\
f \\
u \\
s \\
c \\
i \\
p \\
e \\
s\end{array}$} & 1 & $1.00 \pm 0.0$ & \multirow{5}{*}{$9.66 \pm 1.31$} & \multirow{5}{*}{0.62} & 0.62 & 5.38 & 1 & 0.19 & $\begin{array}{c}0.19(5.38) \\
\times 1\end{array}$ & 1.02 \\
\hline & 2 & $1.92 \pm 0.15$ & & & 1.19 & 4.81 & 0.96 & 0.20 & $\begin{array}{c}0.20(4.81) \\
\times 2\end{array}$ & 1.92 \\
\hline & 4 & $3.50 \pm 0.24$ & & & 2.17 & 3.83 & 0.88 & 0.23 & $\begin{array}{c}0.23(3.83) \\
\times 4\end{array}$ & 3.52 \\
\hline & 8 & $5.49 \pm 0.96$ & & & 3.40 & 2.60 & 0.69 & 0.27 & $\begin{array}{c}0.27(2.60) \\
\times 8\end{array}$ & 5.62 \\
\hline & 16 & $9.66 \pm 1.31$ & & & 5.99 & 0.01 & 0.60 & 0.60 & $\begin{array}{c}0.60(0.01) \\
\times 16\end{array}$ & 9.60 \\
\hline
\end{tabular}

Linear regression analysis was made to establish the relationship between the prey density and the number of prey attacked, the searching time and the attack ratio.

Table 1 Summary of calculations used in analysing the cumulative functional response ( $\left.Y^{\prime}\right)$ for 6 days in $R$. fuscipes (adults) at five different densities of P.lienigianus $(\mathrm{n}=6)$

\section{A. Number of Prey Attacked}

The number of prey killed gradually increased with increasing prey density from 1 prey / predator to 16 prey / predator. The maximum predation was represented by $\mathrm{K}$ value and was restricted to the higher prey density $(\mathrm{K}=9.66 \pm 1.31$ and $6.47 \pm 0.44$ for $R$. fuscipes and $E$. inornatus respectively. Table $1 \& 2$ ). A positive correlation was obtained between the prey density and the prey attacked $(Y=2.089 \times-1.953 ; r=0.96)$ for $R$. fuscipes and $(Y=1.429 x-1.257 ; r=0.974)$ for $E$. inornatus. (fig1)

Positive correlation between prey density and predation was in agreement with the findings Awadallah et al. (1984) in A. biannulipes on stored product pests; Ambrose et al., (2000) in $R$. marginatus on pest of pigeon peas and Claver et al.(2004) in C.spiniscutis on S.litura and H.armigera.

\section{B. Searching Time}

The searching time decreased as the prey density increased from 1 to 16 . It decreased from 5.38 to 0.01 in $R$. fuscipes and 5.33 to -0.02 in $E$. inornatus (table 1\&2). A negative correlation $Y=1.295 x+7.211$; $(r=-0.96 ; Y=-1.329 x+7.243 ; r=-0.960)$ was obtained for $R$. fuscipes and $E$. inornatus respectively. (Fig 2) 
Bibin.G.Anand et al : Ecofriendly Technology for the Management ...

$X=$ Prey density;

$Y=$ Prey attacked;

$\mathrm{k}=\operatorname{maximum} \mathrm{Y} ; \mathrm{b}=$ handling time (in days)

by $=$ days all $Y^{\prime} s ; T s=$ searching time (in days)

$\mathrm{Y} / \mathrm{X}=$ attack ratio;

$\mathrm{a}=$ rate of discovery;

$\mathrm{Tt}=$ total time (in days) for which prey was exposed to the predator.

In both the predators, the searching time (Ts), the interval between successive predation and the handling time decreased as the prey density increased, similar to the findings of Sahayaraj and Ambrose (1996) in $N$. therasii for $D$. cingulatus. They spent lesser time for searching the prey at higher prey densities as observed by senrayan (1999).

\section{Attack Ratio}

The attack ratio decreased as the prey density increased. The highest attack ratio was observed at the density of one prey / predator and the lowest ratio was observed at the density of 16 prey / predator. Like searching time, the attack ratio was also negatively correlated to the prey density $(y=-0.107 x+1.147 ; r=0.974$ for $R$. fuscipes and $y=-0.079 x+0.823 ; r=0.979$ for $E$. inornatus. (Fig 3).

It was similar to the findings of Hassel et al. (1976) stated that the attack rate decreased with increasing prey density in the case of predators having type II functional response. As the satiated bugs would

Table 2. Summary of calculations used in analysing the cumulative functional response $\left(Y^{\prime}\right)$ for 6 days in E. inornatus (adults) at five different densities of $P$. lienigianus $(n=6)$

\begin{tabular}{|c|c|c|c|c|c|c|c|c|c|c|}
\hline & $\begin{array}{l}\text { Prey } \\
\text { density }\end{array}$ & Prey attacked y & $\begin{array}{l}\text { Max } \\
Y(k)\end{array}$ & $\begin{array}{c}\text { Days I } \\
Y \\
b=T t / K\end{array}$ & $\begin{array}{l}\text { Days all } \\
\text { y's (by) }\end{array}$ & $\begin{array}{c}\text { Days } \\
\text { searching } \\
\mathrm{Ts}=\mathrm{Tt}-\text { by }\end{array}$ & $\begin{array}{c}\text { Attack } \\
\text { ratio } y / x\end{array}$ & $\begin{array}{c}\text { Rate of } \\
\text { Discovery } \\
(\mathrm{y} / \mathrm{x}) / \mathrm{Ts}=\mathrm{a}\end{array}$ & $\begin{array}{c}\text { Disc equation } \\
Y^{\prime}=a(T t-b y) x\end{array}$ & $Y^{\prime}$ \\
\hline$E$. & 1 & $0.72 \pm 0.08$ & \multirow{5}{*}{$6.47 \pm 0.44$} & \multirow{5}{*}{0.93} & 0.67 & 5.33 & 0.72 & 0.14 & $0.14(5.33) \times 1$ & 0.75 \\
\hline 1 & 2 & $1.34 \pm 0.13$ & & & 1.25 & 4.75 & 0.67 & 0.14 & $0.14(4.75) \times 2$ & 1.33 \\
\hline 0 & $\overline{4}$ & $2.49 \pm 0.29$ & & & 1.94 & 4.06 & 0.62 & 0.15 & $0.15(4.06) \times 4$ & 2.44 \\
\hline$r$ & 8 & $4.13 \pm 0.38$ & & & 3.84 & 2.16 & 0.52 & 0.24 & $0.24(2.16) \times 8$ & 4.18 \\
\hline $\begin{array}{l}a \\
t \\
u \\
s\end{array}$ & 16 & $6.47 \pm 0.44$ & & & 6.02 & -0.02 & 0.40 & -0.20 & $-0.20(-0.02) \times 16$ & 6.4 \\
\hline
\end{tabular}

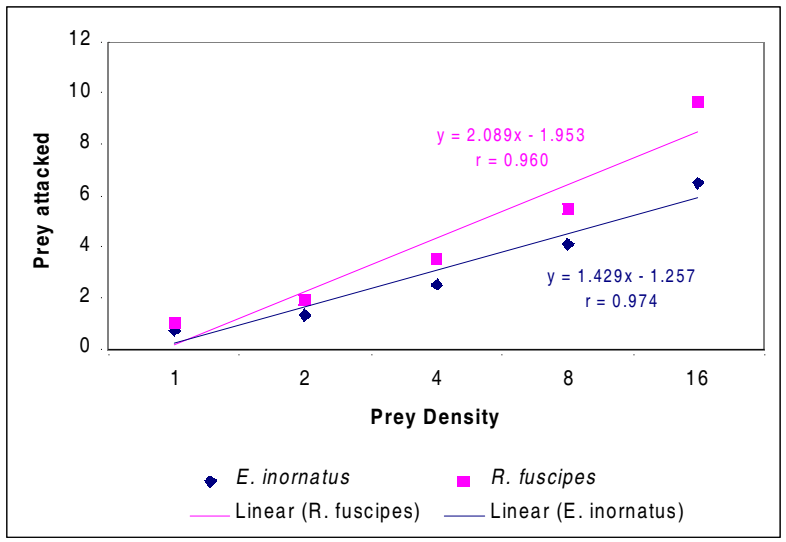

Fig. 1. Regression analysis of the relationship between prey density and prey attacked

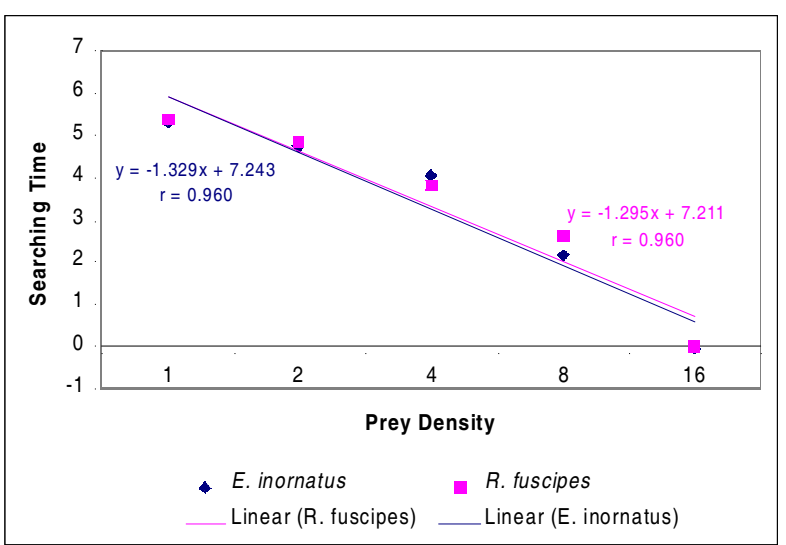

Fig. 2. Regression analysis of the relationship between prey density and searching time 


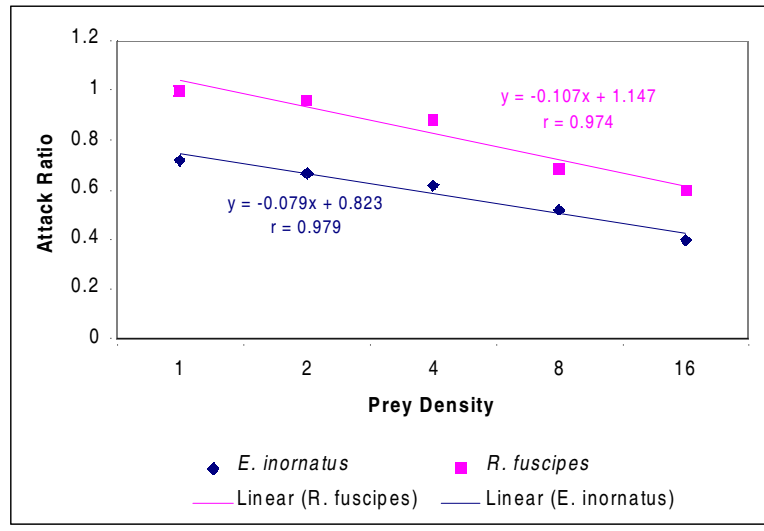

Fig. 3. Regression analysis of the relationship between prey density and attack ratio

not search for another prey the attack rate decreased with the increasing prey density in both the predators.

\section{CONCLUSION}

Although the real efficacy of these predators in bio control programmes could be arrived only after evaluating its numerical response by further investigations, the present investigation on the functional response in $R$. fuscipes and $E$. inornatus suggested that they were capable of suppressing the increasing pest population by killing more number of pest. Hence they could be mass cultured and effectively employed as bio control agents for suppressing pest population of brinjal. At all prey densities R.fuscipes was much quicker and more successful in prey capture and killing, killed more number of preys than $E$. inornatus. This might be due to the inherent difference in the predatory potential of this predator.

The present study also gives an idea about the eco-friendly technology for the management of brinjal pest. It involves strategies like mass rearing of this predators and subsequent large scale release of these predators in the $S$. melongena (brinjal) agro ecosystem to manage insect pests, to minimize the use of pesticides reduce the toxic pollution of the environment and maintain apollutant free and safe environment

\section{REFERENCES}

[1] Ambrose, D.P. 1996, Assassin bugs (Insecta: Heteroptera: Reduviidae) in biocontrol: success and strategies, a review. In: Biological and cultural control of Insect pests, an Indian Scenario. Ambrose D.P. (Editor). Adeline publishers. Tirunelveli. $262-284$.

[2] Ambrose, D.P. Claver, M.A. and Mariappan, P. 2000. Functional response of Rhynocoris marginatus (Heteroptera; Reduviidae) to two pests of pigeon pea(Cajanus cajan). Indi. Journ. Agri. Scien., 70: 630 $-632$.

[3] Awadallah, K.T., Tawfik, M.F.S., Abdellah, M.M.H. 1984. Suppresson effect of the reduviid predator Akllaecoranum biannulipes (Montr. Et sign.) on population of some stored product insect pests. J. Appl. Ent., 97: 249 - 253.

[4] Claver, M.A., Muthu, M.S.A., Ravichandran, B. And Ambrose, D.P. 2004. Behaviour, prey preference and functional response of Coranus spiniscutis (Reuter), a potential predator of Tomato insects pests. Pest Management in Horticultural Ecosystems 10: 19-27.

[5] Hassel, M.P., Lawton, J.H., Beddington, J.R. 1976. The components of arthropod predation I. The prey death - rate. J. Anim. Ecol., 45 : 135 - 164.

[6] Holling, C.S. 1959. Some characteristics of simple type of predation and parasitism. Can.Entamol.,91;385-395.

[7] Mcmahan, E.A.1983.Adaptions, feeding preference and bio metric of a termite baiting assasian bug (Hemiptera:Reduvidae) Ann.Ent.Soc.,Amer.,11;685-689

[8] Sahayaraj, K. And Ambrose, D.P. 1996. Functional response of the reduviid predator Neohaematorrhophis therasii Ambrose and Livingstone to the Cotton stainer Dysdercus cingulatus Fabricius. Biological and cultural control of Insect pests, an Indian scenario. Ambrose, D.P. (ed.), Tirunelveli, India, Adeline Publishers pp. 328- 331.

[9] Senrayan, A. 1998. Functional response of Eocanthcone furellata (Wolff) (Heteroptera; Pentatomidae) in relation to prey density and defence with reference to its prey Latoia lepida(Cramer) (Lepidoptera: Limacodidae); Proc. Indian acad. Sci. (Anim.Sci.) 97; 339 - 345. 